pp. $53-64$

\author{
Monika SZYMAŃSKA \\ ORCID: 0000-0002-4405-1825 \\ Uniwersytet Warszawski
}

\title{
Zdalne nauczanie języka obcego w edukacji przedszkolnej - ujęcie praktyczne
}

\author{
Abstract: Remote Education in the Foreign Language Preschool Education - \\ Practical Approach
}

Even though the children' motivation to learn and cooperate with others is undeniably high, this tendency can still be disturbed by numerous aspects depended on the teacher, such as the classroom management, the selection of teaching aids or methods. This task become even more demanding with the necessity of remote education of preschool children. The aim of this article is to present the practical approach of the remote education in the foreign language preschool teaching process. First, the role of language teaching among the preschool children will be described. The aspects such as special needs and abilities will be emphasized. Secondly, the methods and difficulties of remote language teaching in kindergarten will be presented. Finally, the description of the practical approach will be divided into synchronous and asynchronous solutions, containing some examples of exercises.

Keywords: remote education, internet resources, new technologies, language teaching, preschool education

Słowa kluczowe: nauczanie zdalne, zasoby internetowe, nowe technologie, nauczanie języka, edukacja przedszkolna

\section{Wprowadzenie}

W ostatnich latach nauczanie zdalne, przyjmujące często w całości lub też częściowo formę e-learningu, zyskiwało stopniowe uznanie zarówno w oczach niektórych nauczycieli, jak i uczniów. Metoda ta, wykorzystująca jako podstawę działań przestrzeń internetową, zapewnia prostszy, szybszy i niejednokrotnie skuteczniejszy dostęp nie tylko do niezbędnych informacji, lecz także do zasobów programowych. Wzrastająca popularność nauczania zdalnego spowodowa- 
na była takimi czynnikami, jak chęć zaoszczędzenia czasu czy korzystania z doświadczeń i wiedzy nauczycieli mieszkających $\mathrm{w}$ odległych miejscach świata. Swobodne poruszanie się w środowisku internetowo-technologicznym zachęcało do tego typu nauki także uczniów. Jak trafnie podkreśla Krystyna Łangowska-Marcinkowska (2020), e-learning wpisuje się w model nadzorowanego samokształcenia i doskonale sprawdza się w przypadku słuchaczy potrafiących przejąć kontrolę nad procesem. Zdalne nauczanie daje bowiem wiele możliwości, wykluczając ograniczenia dotyczące przestrzeni czy czasu, a także kwestii ekonomicznych. Kształcenie można podejmować praktycznie z każdego miejsca i o dogodnych porach, sam rytm pracy także nadawany jest przez ucznia.

W obliczu pandemii COVID-19 znacznie szersze grono nauczycieli języków w krótkim czasie zmuszone zostało do podjęcia nowych kroków w celu przeniesienia dotychczas prowadzonych zajęć do rzeczywistości wirtualnej. Nierzadko okazywało się, że jest to teren nieznany, a na pewno znany i doceniany w dużo mniejszym stopniu niż klasyczna sala lekcyjna. Zasoby internetowe okazały się jednak na tyle bogate, że nauczyciele, którzy podjęli to nagłe wyzwanie, odnieśli sukces lub zaakceptowali nową rzeczywistość prowadzenia zajęć. W szczególnie trudnej sytuacji znaleźli się ci, którzy na co dzień zajmowali się nauczaniem przedszkolnym i wczesnoszkolnym, ponieważ, jak zauważa Małgorzata Piotrowska-Skrzypek (2015), dzieci to najbardziej wymagająca grupa uczniów, nieszczędząca słów krytyki i bez wahania okazująca niezadowolenie czy znudzenie, która potrzebuje nauczyciela $z$ charakterem.

\section{Rola edukacji językowej w przedszkolu}

Wobec wzrostu znaczenia i przydatności języków obcych w codziennym życiu wśród osób zapisywanych na kursy językowe coraz częściej pojawiają się uczniowie poniżej szóstego roku życia. Nie dziwi już obecność dwóch języków w przedszkolu, coraz częściej nawet $\mathrm{w}$ żłobku prowadzone są zajęcia $\mathrm{z}$ jednego, dominującego języka obcego - angielskiego. Jak trafnie stwierdza Joanna KicDrgas (2015), wiek między piątym a dziewiątym rokiem życia jest optymalny do rozpoczęcia nauki. Ze względu na zwiększoną plastyczność mózgu możliwe jest wtedy osiągnięcie wyższego poziomu z zakresu umiejętności fonetycznych. Dodatkowo za sprawą ogromnego zaangażowania prawej półkuli nauczanie jest bardziej efektywne. Opisywana nowa tendencja wynika także z rozwojowego podejścia do nauczania języków obcych i szerokiego postrzegania dziecka w procesie nauczania, włączającego do perspektywy umiejętności i potrzeby uczestników kursów. O ile kształcenie osób dorosłych cechuje duża swoboda doboru metod i treści, o tyle współpraca z dziećmi poniżej dziesiątego roku życia okazuje się ograniczona konkretnymi aspektami praktycznymi. Jak trafnie podkre- 
śla Hanna Komorowska (2005), zarówno sam kurs, jak i wybór metod nauczania jest w przypadku dzieci silnie zdeterminowany przez cechy rozwojowe uczestników. Uczniowie objęci edukacją przedszkolną nie nabyli jeszcze umiejętności czytania ani pisania. Rozpoznawanie liter czy cyfr odbywa się $z$ trudnościami i jest bardzo ograniczone. Ponadto dzieci w tym wieku nie potrafią motywować się do pracy i panować nad procesem uczenia się. Mają natomiast potrzebę nie tylko słuchania, ale i ruchu oraz kontaktu $z$ innymi.

Czy w wymiarze praktycznym oznacza to, że zajęcia $\mathrm{z}$ języka obcego w przedszkolu muszą obejmować jedynie ograniczony repertuar powtarzających się ćwiczeń? Zdecydowanie nie. Nauczanie powinno jednak - za Marią Teresą Garcíą Muruais (2014) — przebiegać w zgodzie z osiągnięciami neurodydaktyki kognitywnej, promującej nauczanie przyjazne mózgowi. Zajęcia dedykowane dzieciom poniżej dziesiątego roku życia należy ukierunkować na intensywne osłuchiwanie się z językiem obcym. Podstawową metodą jest włączanie licznych opowiadań oraz bajek, a także nauka piosenek i wierszy, tak by upodobnić ten proces do naturalnego nabywania języka ojczystego. Podczas lekcji trzeba jednak znaleźć przestrzeń zarówno na rutynowe elementy zajęć (powitanie, piosenka, wiersz), jak i elementy zaskakujące (García Muruais, 2014). Zmiana nawet jednego niewielkiego aspektu może przeważyć szalę w walce o uwagę uczestników i chłonność ich umysłów.

W myśl wszelkich założeń metodycznych umiejętności produktywne, takie jak nauka mówienia, powinny na tym etapie pojawiać się w ograniczonym stopniu i często przyjmować formę odtwórczą. Można zatem zapoznawać dzieci z prostymi zdaniami, których zapamiętywaniu sprzyja rymowana forma. Niezastąpiona jest $\mathrm{w}$ tym wypadku także równowaga pomiędzy powtarzaniem a urozmaicaniem (García Muruais, 2014). Stopniowe rozwijanie proponowanych zadań pozytywnie wpływa na poczucie bezpieczeństwa dzieci, jednocześnie sprzyjając zapamiętywaniu. Wprowadzeniem do nauki wypowiadania się jest, jak zauważa Komorowska (2005), prezentacja skontekstualizowanego słownictwa $\mathrm{w}$ formie prostych rymujących się zdań. Proces przyswajania języka przez dzieci cechuje holistyczność. Dzięki prezentowaniu elementów sytuacji zaczerpniętych z życia codziennego uczniowie zyskują możliwość swobodnego i intuicyjnego wykorzystywania zdobywanych umiejętności.

Zgodnie z nową podstawą programową (2017) głównym celem edukacji przedszkolnej w zakresie nauczania języka obcego jest „tworzenie sytuacji edukacyjnych sprzyjających budowaniu zainteresowania dziecka językiem obcym nowożytnym, chęci poznawania innych kultur”. Nauka języka w tym wieku ma zmotywować i przygotować dzieci do rozwijania sprawności językowych w przyszłości. Nie należy proponować ćwiczeń „za wszelką cenę” lub nakłaniać uczniów do przekraczania własnych możliwości. Czytanki, uzupełnianie notatek w zeszycie czy mozolna nauka pisania nie są konieczne podczas pierwszych 
spotkań z językiem obcym i z pewnością nie wpływają pozytywnie na afektywne aspekty lekcji. Należy także wykazać się umiejętnością znalezienia złotego środka pomiędzy elementami językowymi i pozajęzykowymi (García Muruais, 2014).

Prowadzenie zajęć językowych w przedszkolu wiąże się z odejściem od modelu systematycznej nauki na rzecz wspólnego rozwoju i zabawy. O roli tej ostatniej w procesie bardzo ciekawie pisze Monika Cichmińska (2015), wyróżniając jej sześć niewykluczających się wzajemnie typów i podkreślając realia jej funkcjonowania. Podstawowymi atrybutami prawdziwej zabawy są: swoboda, przyjemność, decyzyjność jej uczestników, występowanie elementów nierzeczywistych oraz tzw. przepływ (Csíkszentmihályi, 2005). Uczestnicy gier mogą za ich pomoca manifestować wolność swoich wyborów i czerpać przyjemność z udziału w nich. Nie potrzebują dodatkowej motywacji w postaci nagród czy preliminaryjnych zachęt. Sami ustalają reguły i tworzą nierzeczywiste role oraz światy. Nie odczuwają przy tym stresu ani napięcia, co skutecznie wyklucza możliwość występowania strachu przed porażką czy niepowodzeniem.

Powyższe cechy zabawy to symptom osiągnięcia złotego środka pomiędzy wiedzą kognitywną a emocjami (García Muruais, 2014). Nauka języka obcego przez zabawę nie jest przecież niczym innym, jak kolejnym czynnikiem sprzyjającym naturalnym procesom poznawczym, podobnym do tych aktywizowanych podczas nabywania umiejętności w języku ojczystym. Zabawa uznawana jest za metodę o ogromnym potencjale edukacyjnym, ponieważ zachęca dziecko do podejmowania nowych czynności i stopniowego zwiększania poziomów trudności. Jednocześnie proces doskonalenia umiejętności, realizowany na drodze kolejnych modyfikacji zadań wyjściowych, pozbawiony jest zgubnego aspektu zagrożenia niepowodzeniem. Nauczyciel powinien dążyć do osiągnięcia równowagi między planowaniem zajęć a spontanicznym podejściem do lekcji. Czasem to właśnie dzieci proponują najtrafniejsze modyfikacje zabaw, zgodne ze swoimi potrzebami.

\section{Nauczanie zdalne w edukacji przedszkolnej — trudności i metody}

Choć językowe nauczanie zdalne nie stanowi całkowitego novum, dotychczasowe osiągnięcia w zakresie metod i sposobów prowadzenia zajęć mogą jedynie częściowo ukierunkować współczesne działania nauczycieli. Wynika to ze zmiany podstawowego aspektu klas na odległość: przymusowości. Do tej pory ten model edukacji wybierany był dobrowolnie, najczęściej przez studentów lub osoby dorosłe poszerzające kwalifikacje. Co więcej, niejednokrotnie nauczanie zdalne stanowiło jedynie uzupełnienie tradycyjnie prowadzonych lekcji (Pyżalski, 2020b). W obliczu pandemii COVID-19 niespodziewanie pojawił się przymus, obejmujący także 
tych nauczycieli, którym brak odpowiednich umiejętności z zakresu nowych technologii i nie czują się w wirtualnej rzeczywistości swobodnie.

Podstawowe trudności pojawiające się w kontekście zdalnej edukacji przedszkolnej obejmują kwestie techniczne. Zarówno uczniowie, jak i nauczyciele mieszkający $\mathrm{w}$ różnych miejscach kraju napotykają niejednokrotnie problemy z łączem internetowym. Niedoskonała jakość przekazu, ryzyko rozłączenia czy różne inne problemy techniczne stanowią dodatkowe źródło stresu dla obu stron. Ponadto obsługa sprzętu w przypadku małych dzieci wymaga wsparcia ze strony rodziców, spełniających $\mathrm{w}$ tym czasie własne obowiązki zawodowe. Niejednokrotnie przedszkolaki, które do tej pory nie potrzebowały własnego komputera czy tabletu, są zmuszone do pożyczania sprzętu od rodziców lub starszego rodzeństwa, co nie zawsze jest możliwe w danym momencie. Ograniczenia techniczne mogą stać się przyczyną sporów i nieporozumień, wzrastającego napięcia i stresu, co znacznie utrudnia funkcjonowanie podczas zajęć.

W obliczu tak nagłej i zaskakującej sytuacji każdy, a w szczególności najmłodsi uczestnicy procesu nauczania, może odczuwać silne emocje, spowodowane czynnikami dezorganizującymi dotychczasowe życie. Pojawiający się lęk może prowadzić do kryzysu, charakteryzującego się specyficzną dynamiką (Poleszak, Pyżalski, 2020a). Narastające emocje, takie jak niepewność, złość czy gniew, szybko skutkują doświadczaniem napięcia. Wśród osób dorosłych objawia się ono silnymi reakcjami ucieczkowymi lub zaradczymi. Choć napięcie nie objawia się w taki sam bezpośredni sposób wśród dzieci, pośrednio na nie wpływa. Maluchy obserwują sytuację w domu, czują się odizolowane od rówieśników. Odczuwają lęk spowodowany zwiększonym ryzykiem choroby lub śmierci wśród osób bliskich, a nawet domowników. Pandemia wywołuje także problemy ekonomiczne i narastającą negatywną atmosferę w domu, który do tej pory pełnił funkcję azylu. W tej sytuacji także - a być może szczególnie podczas zajęć — pojawia się potrzeba zwiększonego wsparcia psychicznego, mówienia o emocjach i nacisku na czynniki afektywne występujące $\mathrm{w}$ edukacji przedszkolnej.

Dodatkowym czynnikiem obciążającym młodych uczniów jest nagłe nakładanie na nich większej liczby obowiązków, których wcześniej nie mieli. W znacznie szerszej skali stają się oni odpowiedzialni za system uczenia się, monitorowanie godzin zajęć i zadań domowych. Budzi to u dzieci reakcje stresowe, co - jak zauważa Marek Kaczmarzyk (2020) — prowadzi do obniżenia ogólnej aktywności hipokampów, odpowiedzialnych za proces zapamiętywania oraz przenoszenia doświadczeń do pamięci długotrwałej. Dbałość o emocje i wspieranie ucznia w przeżywaniu nowej sytuacji staje się zatem decydującym czynnikiem w procesie uczenia się i utrwalania nowych umiejętności.

Klasa tradycyjna nie może zostać szczegółowo odwzorowana w wirtualnej rzeczywistości ze względu na specyfikę medium, jakim jest technologia kompu- 
terowa. Z punktu widzenia nauczyciela języków w obliczu nowej sytuacji pojawia się zatem potrzeba znalezienia adekwatnych narzędzi on-line, skutecznie zastępujących metody stosowane podczas zajęć prowadzonych tradycyjnie. $\mathrm{Mu}$ szą się one nie tylko wpisywać w potrzeby uczniów, ale też współgrać z ich umiejętnościami. Bardzo ciekawe ujęcie stanowi model SAMR, opracowany przez dr. Rubena Puendenturę, w myśl którego transformacja klasy na potrzeby rzeczywistości wirtualnej odbywa się podczas czterech faz:

Pierwsza to zastąpienie (ang. substitution) sposobów tradycyjnych technologią bez zmiany typu zadań [...]. Druga faza to rozszerzenie (ang. augmentation): zaczynamy używać funkcji enarzędzia [...]. Faza trzecia [...] to modyfikacja (ang. modification): technologia zaczyna być ważna - nie da się bez niej wykonać zadania, a umiejętności społeczne i cyfrowe ucznia odgrywają znaczącą rolę. [...] Ostatnia, czyli czwarta faza modelu SAMR — redefinicja (ang. redefinition) - wymaga użycia technologii jako narzędzia współpracy uczniów pracujących nad wykonaniem zadania, a rola nauczyciela zmienia się w moderatora i koordynatora procesu nauczania (za: Ścibor, 2020, s. 60).

Choć w językowej zdalnej edukacji przedszkolnej mogą być realizowane jedynie dwa lub trzy pierwsze elementy tego modelu (w zależności od wieku uczniów), stanowi on doskonałe ujęcie transkrypcji nauczania tradycyjnego na jego wersję wirtualną.

Pierwszym krokiem, który należy podjąć, jest skuteczne rozplanowanie całego procesu nauczania zdalnego z uwzględnieniem potrzeb i umiejętności uczestników, liczebności grup oraz wymiaru godzinowego zajęć. Jak wspomina Natalia Walter (2020), warto w tym celu przeanalizować cztery podstawowe zagadnienia: cele edukacji, oczekiwania uczniów, własne umiejętności technologiczne oraz możliwości poznawcze i emocjonalno-społeczne dzieci. Przestrzeń edukacyjna, bez względu na wymiar wirtualny czy realny, musi zostać zorganizowana w przemyślany sposób. Warto dobrać najodpowiedniejszą do tego celu platformę spośród istniejących narzędzi. MS Teams lub Google Classroom umożliwiają odtworzenie w warunkach wirtualnych klasy szkolnej, nie są jednak przydatne w przypadku edukacji przedszkolnej. W tak wczesnym nauczaniu doskonale sprawdzą się ogólnodostępne narzędzia komunikacji, takie jak Skype, Zoom czy Discord.

Bardzo ważnym aspektem jest też gruntowne przeanalizowanie sposobu oraz typu proponowanych dzieciom treści. Zdalne nauczanie może przyjmować formę synchroniczną, polegającą na bezpośrednim połączeniu z grupą, lub asynchroniczną, realizowaną przez wysyłanie materiałów, z którymi uczniowie mają szansę zapoznać się w dogodnym momencie (Doucet i in., 2020). Każde z powyższych rozwiązań ma wiele zalet. Bezpośrednie połączenia z uczniami umożliwiają otrzymywanie natychmiastowych informacji zwrotnych oraz niezbędnych wyjaśnień. Materiały przesyłane asynchronicznie wpływają natomiast na uelastycznienie procesu uczenia się-nauczania i eliminację problemów natu- 
ry logistycznej, dotyczących udostępniania współdzielonego sprzętu lub udzielania wsparcia przez rodziców. W edukacji przedszkolnej doskonałym rozwiązaniem jest łączenie obu tych rozwiązań.

Młodzi ludzie dorastają obecnie w otoczeniu zabawek elektronicznych oraz komputerów, co wpływa na ich obycie w interakcjach zapośredniczonych internetowo. Nawet jednak pokolenie sieci, tak dobrze zaznajomione z mediami cyfrowymi, dozna poczucia przytłoczenia i przemęczenia w wyniku nadmiernego użytkowania technologii. Podstawowymi zasadami, którymi powinien kierować się nauczyciel języka obcego w przedszkolu podczas edukacji zdalnej, jest zatem prostota i umiar. Uczniowie zarzuceni zbyt dużą ilością materiału szybko stracą motywację do uczestniczenia w proponowanych aktywnościach. Nie każde zajęcia powinny być silnie stymulujące wizualnie czy zaskakujące. W doborze materiałów i metod należy kierować się rozsądkiem i znaleźć złoty środek pomiędzy elementami stałymi oraz zmiennymi.

Ze względu na specyfikę sytuacji pandemicznej niezbędnym elementem podczas zdalnej pracy $\mathrm{z}$ dziećmi $\mathrm{w}$ wieku przedszkolnym jest ścisła $\mathrm{i}$ stała współpraca z rodzicami uczniów. Częsta komunikacja pozwala na jasne określanie wymagań oraz wykazywanie się w tym trudnym czasie zrozumieniem, a także elastycznością. Według Jacka Pyżalskiego (2020a) podstawą skutecznej dydaktyki zdalnej jest relacja $z$ uczniami i ich rodzicami oraz wsparcie społeczne. Bez optymalnej działalności w tych dwóch obszarach osiągnięcie sukcesu na poziomie edukacyjnym staje się bardzo utrudnione. Wspólnota przeżyć otwiera zarówno nauczycieli, jak i rodziny uczniów na nowe doświadczenia oraz tworzenie przestrzeni porozumienia. Tego typu relacje realizowane są na czterech płaszczyznach: ustalania wspólnych celów i sposobów działania, przepływu informacji, stałej komunikacji i udzielania wzajemnego wsparcia (Poleszak, Pyżalski, 2020b).

Aby działania podejmowane przez nauczycieli przynosiły oczekiwane rezultaty, prowadzący muszą w pełni ufać swojej ocenie i dotychczas zdobytemu doświadczeniu. Nikt lepiej niż nauczyciel współpracujący od dłuższego czasu z grupą nie zna jej potrzeb, oczekiwań i umiejętności. Rozwiązania sprawdzające się $\mathrm{w}$ rzeczywistości przedpandemicznej, poddane drobnym modyfikacjom, sprawdzą się doskonale w przypadku zajęć wirtualnych (Doucet i in., 2020). Elementem, bez którego nie można się obejść, jest natomiast dążenie do stałego uzyskiwania informacji zwrotnej nie tylko od uczniów, lecz także od wspierających ich rodziców. Tylko na tej podstawie można w rzetelny sposób modyfikować wprowadzane rozwiązania i dopasowywać je do szczegółowych oczekiwań uczestników. Działania tego typu znacząco wpływają na osiągnięcie sukcesu dydaktycznego.

Zdalne nauczanie sprawia, że prowadzący staje przed wieloma nowymi wyzwaniami, które początkowo okazują się bardziej czasochłonne niż przygotowa- 
nie lekcji w tradycyjnej formie. Warto jednak korzystać z zasobów istniejących w sieci zamiast usilnie tworzyć nowe, podobne do dostępnych treści. Wraz z pojawieniem się pandemii COVID-19 wzmogły się ruchy solidarnościowe, jednoczące nauczycieli chętnych do dzielenia się nie tylko materiałami, lecz także pomysłami nowych rozwiązań (Koludo, 2020). Dołączanie do społeczności, wyszukiwanie najodpowiedniejszych dla uczniów treści i dzielenie się własnymi uwagami wpływa na poczucie przynależności do wspierającej się grupy i wzmaga chęć twórczej pracy.

\section{Rozwiązania synchroniczne - ujęcie praktyczne}

Praktyczna część opracowania ma na celu przedstawienie rozwiązań synchronicznych oraz asynchronicznych, stosowanych $\mathrm{w}$ zdalnej edukacji językowej dzieci w wieku przedszkolnym. Została stworzona na podstawie doświadczeń autorki zdobytych podczas pracy $\mathrm{w}$ jednym $\mathrm{z}$ niepublicznych przedszkoli integracyjnych językowo-muzycznych w Warszawie. Przedstawione metody wykorzystywano podczas nauczania języka angielskiego w pięciu grupach, wśród dzieci od trzeciego do szóstego roku życia, od marca do czerwca 2020 r. W tradycyjnej formie zajęcia odbywały się cztery razy w tygodniu i trwały 30 minut dla dzieci trzy-, czteroletnich oraz 40 minut dla dzieci pięcio-, sześcioletnich. Formuła zajęć podczas wprowadzonego wówczas w kraju ograniczenia przemieszczania została zmodyfikowana i dopasowana do potrzeb oraz umiejętności uczestników.

W ramach jednych zajęć w tygodniu zdecydowano się na wprowadzenie rozwiązania synchronicznego. Powyższa decyzja podyktowana została względami praktycznymi. Poza lekcjami języka angielskiego dzieci uczestniczyły także w zajęciach ogólnoedukacyjnych, muzycznych oraz z języka francuskiego. Czas spędzany przed ekranem w ciągu dnia oraz stopień zaangażowania rodziców nie pozwoliły na zwiększenie częstotliwości spotkań synchronicznych. Lekcje organizowane były za pomocą ogólnodostępnej platformy komunikacyjnej Zoom.us, umożliwiającej tworzenie połączeń konferencyjnych nieograniczonych czasowo. Spotkania trwały od 30 do 40 minut, w zależności od grupy wiekowej.

Mimo że grupy w objętym badaniem przedszkolu liczyły od 8 do 12 osób, bardzo szybko okazało się, że podczas zdalnego prowadzenia zajęć językowych przydatne jest wsparcie drugiej osoby. Pełni ona funkcję moderatora, a do jej obowiązków należy zarządzanie dźwiękiem i dopuszczanie do głosu kolejnych uczestników, a także tworzenie osobnych pokoi podczas zadań grupowych. Częściowe odciążenie nauczyciela $\mathrm{w}$ kwestiach technicznych znacząco wpłynęło na poprawę jakości prowadzonych zajęć w języku obcym. Pozwoliło na płynne prezentowanie kolejnych materiałów i realizację wszystkich założonych celów 
w wyznaczonym na zajęcia czasie. Lekcje prowadzone w sposób synchroniczny za pomocą platform komunikacyjnych powinny odbywać się w grupach nie większych niż dwunastoosobowe. Daje to nauczycielowi szansę na poświęcenie uwagi każdemu uczestnikowi i zachęcenie do aktywności w optymalnym stopniu. Jest to szczególnie istotne na pierwszym etapie edukacyjnym, podczas którego dzieci osłuchują się z językiem, a prowadzący zwraca szczególną uwagę na aspekty fonetyczne zajęć.

Konstrukcja każdych zajęć powinna obejmować elementy stałe, znane dzieciom, zapewniające poczucie bezpieczeństwa oraz $\mathrm{w}$ zrównoważonym stopniu elementy zaskakujące. Można zatem wprowadzić w ramach powitania wiersz lub piosenkę, wyraźnie wyznaczając granicę rozpoczęcia lekcji i zakończenia etapu organizacji technicznej. Trzon zajęć warto skonstruować wokół ćwiczeń wykorzystujących elementy dramy. Wprowadzane na tym etapie słownictwo powinno być konkretne, odnosić się do rzeczywistości znanej dzieciom z codziennych czynności. Łatwo zatem zastąpić wykorzystywane w tradycyjnej klasie karty obrazkowe przedmiotami codziennego użytku, np. owocami, ubraniami czy zabawkami. Nauczyciel może wykorzystywać do prezentacji maskotki, przeniesione do rzeczywistości wirtualnej z sali przedszkolnej. Warto także zachęcać dzieci do odszukiwania tych przedmiotów w domu. Pozytywnie wpłynie to na utrwalanie słownictwa i urozmaici zajęcia, pozwalając się oddalić od komputera.

Innym ciekawym rozwiązaniem jest wprowadzenie podczas zdalnie prowadzonych zajęć konwencji przebrań i wywiadu. Nauczyciel występujący przed dziećmi w nietypowym stroju lub w nietypowym towarzystwie może stanowić doskonałe urozmaicenie i przyciągnąć uwagę grupy. Nadawanie cech ludzkich pluszakom, owadom lub pojedynczym przedmiotom użytku codziennego oraz zachęcanie uczestników do dialogu to okazja do aktywizacji grupy i przemycenia przydatnych struktur w języku obcym. Prowadzone zajęcia uzależnione są od możliwości przestrzennych nauczyciela. Nowoczesne technologie umożliwiają łączenie się z dziećmi za pomocą tabletu lub telefonu z różnych miejsc, niekoniecznie $\mathrm{z}$ domu. Warto eksperymentować z przenoszeniem klasy do ogrodu, na strych i tworzeniem w ten sposób konwencji gry. Zabawa to nieodłączny element zajęć językowych w przedszkolu, dlatego nie należy bać się proponowania jej zmodyfikowanych wersji również w przestrzeni wirtualnej.

\section{Rozwiązania asynchroniczne - ujęcie praktyczne}

Podczas przeprowadzania edukacji zdalnej $\mathrm{w}$ jednym $\mathrm{z}$ integracyjnych przedszkoli niepublicznych językowo-muzycznych w Warszawie zdecydowano się na wprowadzenie rozwiązań asynchronicznych podczas trzech spośród czterech lekcji języka obcego w tygodniu. Wybrane rozwiązania zostały dopasowane do 
potrzeb i umiejętności uczniów z różnych grup wiekowych. Proponowane materiały nawiązywały tematycznie do prowadzonych raz $\mathrm{w}$ tygodniu zajęć synchronicznych i stanowiły ich uzupełnienie. Dzieci, zapoznając się z przesyłanymi propozycjami ćwiczeń, miały możliwość utrwalania zdobywanych w danym tygodniu umiejętności.

Jednym $z$ interesujących rozwiązań asynchronicznych jest tworzenie nagrań półinteraktywnych na bazie kart opowieści, proponowanych przez liczne wydawnictwa edukacyjne. Warto obrać przy nich motyw przewodni, zaczerpnięty np. z bajki znanej dzieciom, by dodatkowo zachęcić je do pracy i wprowadzić stały element nagrań (np. intro). W tworzonych na potrzeby prowadzonych przez autorkę zajęć motywem takim były zabawy z Myszką Miki. Proste pytania dotyczące prezentowanych na obrazkach postaci, przedmiotów lub pomieszczeń poprzedzone były czytanymi przez nauczyciela w języku angielskim kartami opowieści. Odpowiedź wyświetlana na ekranie pojawiała się dopiero po upływie kilku sekund, tak by dziecko, odpowiednio do tego zachęcone, najpierw poszukało jej we własnym zakresie. W podobny sposób organizowane były kolejne zadania, wykorzystujące popularne motywy gry w memory, bingo, układanie domina czy puzzli. Jeśli nauczyciel nie jest zanadto ograniczony miejscem, w podobny sposób można stworzyć nagrania w innej, zaskakującej przestrzeni. Łatwo wykorzystać do tego elementy zagadki i tajemnicy, proponując zabawę w poszukiwanie skarbu.

W zasobach internetowych istnieje wiele przydatnych, darmowych narzędzi umożliwiających tworzenie atrakcyjnych materiałów asynchronicznych. Jednym $z$ nich jest platforma storyjumper.com, na której po uprzednim zalogowaniu można tworzyć własne opowieści w formie książki. Choć jest to rozwiązanie dosyć czasochłonne i wymagające od nauczyciela kreatywności, zapewnia możliwość całkowitego dopasowania materiału do poziomu uczniów. Prowadzący ma do dyspozycji liczne obrazy, za pomocą których tworzy ilustrowaną historię. Platforma umożliwia także zamieszczenie tekstu oraz nagrania go do każdej ze stworzonych stron. Dzięki temu nauczyciel może utrwalić czytaną przez siebie opowieść, znacząco odciążając rodziców ucznia, którzy nie zawsze mają odpowiednie umiejętności czytania w języku obcym. W przypadku młodszych grup przydatne okazuje się nagrywanie tłumaczeń proponowanych materiałów, by zwiększać poczucie bezpieczeństwa wśród dzieci. Innym rozwiązaniem jest korzystanie $z$ istniejących już otwartych zasobów edukacyjnych. Archive.com to biblioteka internetowa umożliwiająca wypożyczanie dostępu do książek w wielu językach i na wielu poziomach zaawansowania. Dostęp po uprzednim zalogowaniu jest darmowy. Nauczyciel nie musi zatem tworzyć własnych zasobów, lecz może korzystać z już istniejących. Nagrywanie ich czytanej wersji może odbywać się za pomocą komunikatora Zoom.us lub innych dostępnych narzędzi. 
Podczas zajęć językowych na poziomie przedszkolnym zadaniem nauczyciela jest osłuchiwanie dzieci z melodyką języka oraz tworzenie fundamentów dalszej nauki. Zajęcia realizowane są przez wprowadzanie skontekstualizowanych zasobów leksykalnych dotyczących życia codziennego. Dobrym sposobem na zakorzenienie słownictwa $\mathrm{w}$ kontekście jest budowanie krótkich rymowanych zdań w języku obcym, wspomagających zapamiętywanie. Stanowią one atrakcyjną formę nauki zarówno dla dzieci, jak i dla nauczyciela, który ma okazję włączenia elementów kreatywnych do codzienności. Podczas nauki zdalnej może on tworzyć prezentacje, w których rymy przedstawiane są za pomocą ilustracji, a całości dopełnia zaskakujący podkład muzyczny.

Bitmoji to znane zarówno młodszym, jak i starszym użytkownikom internetu spersonalizowane emotikony. Po stworzeniu osobistego wyrazistego awatara wystarczy wyszukać i pobrać naklejki, na których jest on widoczny podczas wykonywania rozmaitych czynności. Zabawy z naklejkami Bitmoji to doskonała okazja do poszerzania zasobu leksykalnego. Mogą być one wykorzystywane do tworzenia prezentacji przez nauczyciela lub do aktywizowania uczniów podczas zajęć i zachęcania ich do indywidualnych czy grupowych zabaw językowych.

\section{Podsumowanie}

Zdalne nauczanie języka obcego w edukacji przedszkolnej to szerokie, stale rozwijające się zagadnienie o ogromnym potencjale. Realizowane jest ono w dwóch ścieżkach: synchronicznej, a także asynchronicznej. Ich dobór i proporcja, podobnie jak adaptacja metod nauczania i celów lekcji, warunkowane są umiejętnościami oraz potrzebami uczniów. Decyzję o ostatecznym kształcie edukacji w danej placówce podejmuje prowadzący zajęcia, ograniczany jedynie własną wyobraźnią i kreatywnością. W pracy nauczyciela nie należy wystrzegać się nieszablonowych rozwiązań, jeśli przynoszą one pożądane efekty. Już wcześniej szeroki zakres obowiązków współczesnych pedagogów zostaje dodatkowo urozmaicony w pandemicznej rzeczywistości. Nauczyciel staje się aktorem, psychologiem, mentorem, reżyserem oraz grafikiem komputerowym. Naucza, wspiera, inspiruje, prowadzi, odgrywając swoje role bez wahania, w trosce o dobro i rozwój podopiecznych. 


\section{Bibliografia}

Cichmińska, M. (2015). Bawię się, więc jestem. „Języki Obce w Szkole”, 1, s. 13-16.

Csíkszentmihályi, M. (2005). Przeptyw. Fak poprawić jakość życia. Psychologia optymalnego doświadczenia. Przeł. M. Wajda-Kacmajor. Taszów: Moderator.

Doucet, A., Netolicky, D., Timmers, K., Tuscano, J. (2020). Thinking about Pedagogy in an Unfolding Pandemic School Closures, https://issuu.com/educationinternational/docs/2020_research_ covid-19_eng (dostęp 14 III 2020).

García Muruais, M. T. (2014). Neurodydaktyka w nauczaniu języka hiszpańskiego dzieci w wieku przedszkolnym - cud równowagi. „Języki Obce w Szkole”, 2, s. 59-64.

Kaczmarzyk, M. (2020). Neurobiologiczny kontekst edukacji zdalnej. W: J. Pyżalski (red.), Edukacja w czasach pandemii wirusa COVID-19. Z dystansem o tym, co robimy obecnie jako nauczyciele. Warszawa: EduAkcja

Kic-Drgas, J. (2015). Czym skorupka za młodu nasiaknie..., czyli kilka uwag o ksztatceniu interkulturowym najmłodszych. „Języki Obce w Szkole”, 1, s. 36-42.

Koludo, A. (2020). Strategie kształcenia na odlegtość. W: J. Pyżalski, Edukacja w czasach pandemii wirusa COVID-19. Z dystansem o tym, co robimy obecnie jako nauczyciele. Warszawa: EduAkcja, s. $43-50$.

Komorowska, H. (2005). Metodyka nauczania języków obcych. Warszawa: Fraszka Edukacyjna.

Łangowska-Marcinkowska, K. (2020). Nauczanie zdalne (e-learning) cecha nowoczesnych technologii w edukacji. „Pedagogika Przedszkolna i Wczesnoszkolna”, 2 (16), s. 63-69.

Piotrowska-Skrzypek, M. (2015). Kompetencje nauczyciela języka obcego w przedszkolu. „Języki Obce w Szkole", 1, s. 23-30.

Poleszak, W., Pyżalski, J. (2020a). Psychologiczna sytuacja dzieci i młodzieży w dobie epidemii. W: J. Pyżalski (red.), Edukacja w czasach pandemii wirusa COVID-19. Z dystansem o tym, co robimy obecnie jako nauczyciele. Warszawa: EduAkcja, s. 7-15.

Poleszak, W., Pyżalski, J. (2020b). Relacje przede wszystkim - nawet jeśli obecnie jedynie zapośredniczone. W: J. Pyżalski (red.), Edukacja w czasach pandemii wirusa COVID-19. Z dystansem o tym, co robimy obecnie jako nauczyciele. Warszawa: EduAkcja, s. 28-36.

Pyżalski, J. (2020a). Co jest obecnie ważne, a co mniej w działaniach szkót i nauczycieli? W: Pyżalski, J. (red.), Edukacja w czasach pandemii wirusa COVID-19. Z dystansem o tym, co robimy obecnie jako nauczyciele. Warszawa: EduAkcja, s. 25-27.

Pyżalski, J. (2020b). Wstęp. W: J. Pyżalski, Edukacja w czasach pandemii wirusa COVID-19. Z dystansem o tym, co robimy obecnie jako nauczyciele. Warszawa: EduAkcja, s. 2-6.

Ścibor, J. (2020). Wstrzymaj siebie, rusz ucznia: E-nauczanie a e-twórczość. W: J. Pyżalski (red.), Edukacja w czasach pandemii wirusa COVID-19. Z dystansem o tym, co robimy obecnie jako nauczyciele. Warszawa: EduAkcja, s. 59-63.

Walter, N. (2020). Mamy (za) duży wybór — jak nie zgubić się wśród narzędzi cyfrowych? W: J. Pyżalski (red.), Edukacja w czasach pandemii wirusa COVID-19. Z dystansem o tym, co robimy obecnie jako nauczyciele. Warszawa: EduAkcja, s. 51-58.

Rozporządzenie Ministra Edukacji Narodowej z dnia 14 lutego 2017 r. w sprawie podstawy programowej wychowania przedszkolnego oraz podstawy programowej kształcenia ogólnego dla szkoły podstawowej, w tym dla uczniów z niepełnosprawnością intelektualną w stopniu umiarkowanym lub znacznym, kształcenia ogólnego dla branżowej szkoły I stopnia, kształcenia ogólnego dla szkoły specjalnej przysposabiającej do pracy oraz kształcenia ogólnego dla szkoły policealnej. DzU, 2017, poz. 356. 